\title{
PENGEMBANGAN BOOKLET SEJARAH PEREKONOMIAN LOKAL UNTUK MAHASISWA PENDIDIKAN SEJARAH
}

\author{
Oleh : \\ Najuah \\ Abdul Haris Nasution
}

\begin{abstract}
The challenge of the beginning of the econmy local history development. Interest Study of econmoy Local history in the colonial. The background of this research is necessary the developing of the history material lesson with local economy history material in the colonial. Because of lack of material in accordance with KKNI 2013 Curiculum. The characteristic of the targets and the needs of studnts and some relics of the local history in East Sumatra in the colonial underutilized in learning history. Plug Scientific and Technological progress more sophisticated so that students lazy to seek and read the history books. For it, the researchers developed history material lesson used RnD method (Research and Development) that is research used to product certain products and test products effectivenese. Purpose of this research are : (1) describe material lesson that during this time used in history about economy local history in the colonial in East Sumatra for student at third semester in JPS FIS Unimed, (2) product mateial lesson according to the needs of the history learning especially economy local history substance for students, (3) knowledge and analyzed effectivenese of material lesson that developed in economy local hisory learning about interest study for students. The result of research howing (1) the developed of material lesson shaped economy local history substance in colonial (2) students more understanding with economy local history in colonial, students activity involved in laerning-teaching process and more motivated and easy to understand history lesson, interest study and curiousity of students more high, and (3) the booklet effectivenese give the positive influence to interest study. The conclusion of this research are (1) the developing of history lesson material through two steps testing by expert team (2) application of history lesson material can make students more interest to study history, brave argued opinion, active in learning process and respect for opinions other people, (3) application of developing of history lesson material has did by research give the positive influence for interest study of students. Based on same of the above conclusions, researcher ask the suggestion as here. The teacher should start to develop materials in accordance with the curiculum, the good lesson material should comply all effective, efficient and innovative criteria and following the development of science nad technology.
\end{abstract}

Keywords : history lesson material, bookled, economy local history. 


\section{PENDAhuluan}

Pembelajaran merupakan sebuah proses yang memadukan segenap komponen untuk berjalan secara bersinambung. Dalam hal ini Pembelajaran Sejarah yang berfungsi menanamkan nilai-nilai dari peristiwa sejarah yang dipelajari melalui pembelajaran dikelas kepada mahasiswa. Pembelajaran adalah proses interaksi peserta didik dengan pendidik dan sumber belajar pada suatu lingkungan belajar. Oleh karena itu dalam pembelajaran harus terjadi sebuah proses timbal balik dengan optimalisasi peran dari masing-masing komponen, baik dari dosen dalam melakukan perencanaan, pemilihan model dan pemilihan bahan ajar atau sumber belajar.

Bahan ajar memiliki posisi yang sangat penting dalam pembelajaran, yaitu sebagai representasi (wakil) dari penjelasan dosen di depan kelas dan juga sebagai komponen untuk pencapaian kompetensi pembelajaran. Dalam proses kegiatan belajar mengajar di kelas, seorang dosen harus menentukan bahan ajar apa yang akan dipakai atau yang akan digunakan agar dapat mencapai Standar Kompetensi (SK) yang sudah ditentukan.

Berdasarkan Undang-Undang Sisdiknas No.20 tahun 2013 dijelaskan bahwa kewajiban dosen sebelum mereka berdiri di depan kelas adalah menciptakan suasana pendidikan yang bermakna, kreatif, dinamis, dan dialogis dan mempunyai komitmen secara profesional untuk meningkatkan mutu pendidikan. Tanpa memperhatikan apakah pemerintah sudah menyediakan buku pembelajaran, buku dosen, silabus, dan buku pedoman dosen. Dosen wajib membuat bahan ajar yang dibutuhkan oleh mahasiswa selama buku sejarah ekonomi yang masih kurang dan tidak memenuhi harapan dosen dan mahasiswa.

Bahan ajar inilah yang menjadi salah satu persoalan dalam pembelajaran sejarah yang fungsinya sebagai komponen pembentukan karakter atau penanaman nilai melalui peristiwa pembelajaran tidak berjalan sebagaimana mestinya. Salah satunya yakni, penyediaan bahan ajar atau buku sejarah ekonomi di perpustakaan yang tidak ada dan digunakan hanya buku-buku dari dosen yang membahas sejarah secara spasial yang acapkali meninggalkan sejarah lokal. Terlepas dari batasan geografis dalam 
pengertian sejarah lokal, khususnya dalam pembelajaran sejarah idealnya berangkat dari masalah dan fenomena lokal, agar mahasiswa mempunyai perasaan memiliki dan membutuhkan terhadap matakuliah yang disampaikan.

Selama ini proses pembelajaran sejarah bermuatan sejarah lokal masih sangat rendah untuk dikembangkan dalam kurikulum KBK 2008 mata pelajaran sejarah ekonomi lokal. Rendahnya kesadaran dosen dalam menggali lokal genius(kearifan lokal) sebagai bahan ajar menjadikan mahasiswa tidak mampu mengenali sejarah lokalnya sendiri apalagi untuk dijadikan sebuah kebanggaan lokal masih sangat jauh dari internalisasinya. Contohnya saja tokoh-tokoh daerah dalam peperangan melawan kolonial, banyak tidak dikenal oleh mahasiswa di wilayah atau daerahnya sendiri. Dengan tidak dikenalnya pahlawan dari daerahnya tidak menimbulkan kebanggan diri dalam dirinya. Selain itu minat belajar mahasiswa juga terpengaruhi dengan pengadan bahan ajar ini. Hal ini terjadi karena pembelajaran sejarah dikampus hanya menggunakan bahan ajar yang diberikan dosen yang membahas sejarah secara Nasional dan dosen sejarah tidak melakukan pengembangan bahan ajar sejarah untuk kebutuhan pembelajaran yang mengajarkan sejarah lokal yang merupakan bagian dari sejarah Nasional.

Dari permasalahan yang terjadi dalam pembelajaran sejarah di kampus terkait dengan bahan ajar yang tidak menyertakan sejarah lokal, maka perlu dilakukan inovasi dalam penyediaan bahan ajar. Yakni dengan melakukan pengembangan bahan ajar dengan dimanfaatkannya sejarah lokal pada pembelajarn sejarah untuk mengangakat sejarah lokal kedalam pembelajaran sejarah yang nantinya menanamkan nilai lokal kepada mahasiswa dan meningkatkan minat belajar mahasiswa tehadap pembelajaran sejarah.

Penelitian ini menggunakan pendekatan penelitian dan pengembangan atau Reseach and Development (R\&D) yang merupakan metode penelitian yang digunakan untuk menghasilkan produk tertentu, dan menguji keefektifan produk tersebut. Langkah-langkah dalam penelitian Research and Development meliputi: (1) potensi dan masalah, (2)pengumpulan data, (3) desain produk, (4) validasi desain, (5) ujicoba 
pemakaian, (6) revisi produk, (7) ujicoba produk, (8) revisi desain, (9) revisi produk, (10) produksi massal. Akan tetapi, dalam penelitian ini langkah-langkah penelitian diringkas menjadi tiga tahapan yang di dalamnya terdapat10 langkah tersebut. Namun, peneliti mencoba menyederhanakan pengembangan bahan ajar berbentuk booklet ini menjadi, (i) Potensi dan Masalah, (2) pengumpulan data, (3) Desain Produk, (4) Validasi Desain, (5) Uji coba pemakaian, (6) Evaluasi Produk.

\section{PEMBAHASAN}

Hasil penelitian pengembangan buklet dalam pembelajaran sejarah lokal perekonomian meliputi analisis kebutuhan pengembangan buklet, penilaian kelayakan desain, uji coba awal dan uji coba pemakaian. Hasil pengisian angket kebutuhan menunjukkan bahwa Mahasiswa memberikan tanggapan yang positif mengenai adanya buklet sejarah perekonomian dan merasa tertarik dengan materi serta tugas dalam buklet. Penilaian kelayakan desain dilakukan oleh validator materi dan media. Hasil analisis terhadap penilaian pakar digunakan untuk merevisi buklet yang dikembangkan. Buklet yang dikembangkan telah memenuhi kriteria kelayakan, maka buklet siap untuk diujicobakan pada kelompok terbatas.

Hasil penilaian kelayakan dari validator materi dan media dapat dilihat pada Tabel 1.

Tabel 1. Penilaian kelayakan buklet oleh validator

\begin{tabular}{|c|c|c|c|}
\hline No. & Penilaian Validator & Skor & Kriteria \\
\hline 1 & Materi & $91 \%$ & Sangat Layak \\
\hline 2 & Media & $92 \%$ & Sangat Layak \\
\hline Rata-rata & & $91,5 \%$ & Sangat Layak \\
\hline
\end{tabular}

Penilaian kelayakan buklet sebagai sumber belajar materi sejarah perekonomian menggunakan instrumen penilaian kelayakan materi dan instrumen penilaian kelayakan media. Buklet sebagai sumber belajar materi sejarah lokal perekonomian memenuhi kriteria skor penilaian dari validator materi dan media $>62,5 \%$. Penilaian dari validator materi buklet ini memiliki kelebihan antara lain pada komponen isi materi adalah sesuai dengan kompetensi inti, kompetensi dasar, dan 
kebutuhan bahan ajar serta pertanyaan yang tercantum memuat seluruh indikator pembelajaran. Komponen desain pembelajaran buklet memiliki kelebihan karena berpusat pada mahasiswa, sesuai dengan tujuan pembelajaran serta mampu merangsang kedalaman berpikir siswa. Hal tersebut didukung oleh Nur (2012) yang menyatakan bahwa untuk memilih buku teks pelajaran perlu mempertimbangkan isi buku mencakup ketepatan konsep, keaktualan informasi, kesesuaian contoh, dan keluasan serta kedalaman materi. Penilaian dari validator media, kelebihan buklet ini terletak pada kemudahan penggunaan dan kesederhanaannya. Komponen desain media buklet ini memiliki kelebihan tampilan yang komunikatif, kreatif serta penyajian ilustrasi, tabel, dan foto sehingga dapat memudahkan siswa menyerap materi. Mukminan menyatakan bahwa untuk mengembangkan media pembelajaran perlu memperhatikan prinsip VISUALS, singkatan dari: (1) Visible : Mudah dilihat, (2) Interesting : Menarik, (3) Simple : Sederhana, (4) Useful : Isinya bermanfaat, (5) Accurate : Benar (dapat dipertanggungjawabkan), (6) Legitimate : Masuk akal atau sah, dan (7) Structured: Terstruktur atau tersusun dengan baik (Nurseto 2011).

Uji coba awal dilakukan untuk memperoleh respon dan komentar Mahasiswa mengenai keterbacaan buklet oleh 34 mahasiswa kelas Reg A 2015. Secara keseluruhan siswa pada uji coba awal memberikan tanggapan positif terhadap buklet materi Sejarah lokal perekonomian. Rekapitulasi angket Mahasiswa terhadap keterbacaan buklet tercantum pada Tabel 2.

Tabel 2. Rekapitulasi angket uji coba skala terbatas No.1

\begin{tabular}{|l|l|c|c|}
\hline \multicolumn{2}{|c|}{ Pernyataan } & \multicolumn{2}{l|}{ Tanggapan (\%) } \\
\hline \multicolumn{2}{|c|}{ Ya } & \multicolumn{2}{|c|}{ Tidak } \\
\hline 1. & Kemenarikan buklet & 100 & 0 \\
\hline 2. & Kejelasan tulisan dalam buklet & 97 & 3 \\
\hline 3. & Kejelasan dan kemudahan bahasa yang digunakan & 82,5 & 17,5 \\
\hline 4. & Penyajian yang sederhana dan tidak rumit & 94 & 6 \\
\hline 5. & Penggunaan jenis dan ukuran huruf & 76 & 24 \\
\hline 6. & Penggunaan gambar untuk memudahkan belajar & 94 & 6 \\
\hline 7. & Warna latar belakang yang kontras/mudah dibedakan & 88 & 12 \\
\hline 8. & Kepraktisan buklet & 100 & 0 \\
\hline Rata-rata & $\mathbf{9 1 , 5}$ \\
\hline
\end{tabular}


Mahasiswa memberikan tanggapan dengan skor rata-rata sebesar 91,5\%. Hasil ini telah mencapai $\geq 75 \%$ dengan kriteria sangat layak. Kekurangan dari buklet menurut mahasiswa adalah ukuran huruf yang terlalu tebal dan besar pada bagian materi serta desain cover yang kurang menarik. Kekurangan tersebut direvisi dengan mengubah huruf dari bold menjadi normal, memperkecil ukuran huruf, dan merevisi desain. Masukan yang didapat dari uji coba awal adalah keterbacaan teks. Menurut mahasiswa, pada beberapa halaman, tulisan tidak terbaca khususnya dalam tabel karena masalah pencetakan yang kurang baik. Hal ini diperbaiki dengan cara mengganti resolusi pada printer. Saran dari mahasiswa pada uji coba awal dijadikan pedoman untuk melakukan perbaikan. Setelah revisi selesai selanjutnya buklet sejarah lokal perekonomian yang dikembangkan diujicobakan pada lingkup mahasiswa yang lebih luas.

Setelah uji coba awal dan revisi produk, dilanjutkan dengan uji coba pemakaian. Uji coba pemakaian dilakukan untuk memperoleh data tanggapan mahasiswa terhadap buklet berbasis penelitian dalam pembelajaran, dan hasil belajar mahasiswa yang meliputi aspek kognitif dan afektif.

Uji coba pemakaian buklet dalam pembelajaran dilakukan dua kali pertemuan terhadap 69 siswa (35 mahasiswa kelas C Reguler 2015 dan 34 mahasiswa kelas A Reguler 2015) Jurusan Pendidikan Sejarah Unimed. Rekapitulasi hasil belajar kognitif Mahasiswa dapat dilihat pada Tabel 3.

Tabel 3. Hasil belajar siswa pada uji coba pemakaian Kelas

\begin{tabular}{|l|l|l|l|l|}
\hline Results Of The Study & Highest & Lowest & $\begin{array}{l}\text { Average } \\
\text { Class }\end{array}$ & $\begin{array}{l}\text { Percentage } \\
\text { Complete } \\
\text { KKM (\%) }\end{array}$ \\
\hline C Regular 2015 & 92 & 74 & 86,7 & 93 \\
\hline A Regular 2015 & 92 & 76 & 85,2 & 94 \\
\hline Average & \multicolumn{3}{|c|}{93,5} \\
\hline
\end{tabular}

Ketuntasan hasil belajar mahasiswa kelas C Reguler 2015 mencapai 93\% dengan rerata kelas 86,7 dan kelas A Reguler 2015 mencapai ketuntasan sebesar 94\% dengan rerata kelas 85,2. Ketuntasan hasil belajar kelas C Reguler 2015 sebesar 93\% artinya jumlah mahasiswa yang memperoleh nilai $\geq 80$, berjumlah 33 dari 35 mahasiswa. Ketuntasan hasil belajar kelas A Reguler 2015 sebesar 94\% artinya jumlah 
mahasiswa yang memperoleh nilai $\geq 80$, berjumlah 32 dari 34 mahasiswa. Rata-rata persentase ketuntasan hasil belajar mahasiswa mencapai 93,5\%. Data hasil belajar kedua kelas kemudian dianalisis secara statistika untuk mengetahui perbedaannya menggunakan uji t. Berdasarkan hasil uji t diperoleh bahwa pada $\alpha=5 \%$, thitung $<$ ttabel sehingga tidak terdapat perbedaan yang signifikan antara rata-rata hasil belajar kelas A Reguler dan C Reguler.

Perbedaan hasil belajar mahasiswa di kelas A Reguler dan C Reguler dapat disebabkan oleh rendahnya motivasi dan minat mahasiswa. Menurut Sianipar (2010) keberhasilan atau prestasi mahasiswa dalam belajar pada dasarnya dipengaruhi oleh beberapa faktor yang saling terkait, baik internal maupun eksternal. Hal ini berarti tidak ada faktor tunggal yang berdiri sendiri dan secara otomatis menentukan keberhasilan atau prestasi seseorang dalam belajar. Salah satu faktor yang dapat mempengaruhi keberhasilan belajar mahasiswa adalah pemanfaatan sumber belajar.

Pada akhir pembelajaran, mahasiswa memberikan tanggapan yang baik terhadap penggunaan buklet sebagai sumber belajar materi pencemaran sejarah lokal dengan rata-rata persentase siswa yang menjawab "Ya" diperoleh dari angket sebesar 92,5\%. Rekapitulasi hasil angket tanggapan mahasiswa dapat dilihat pada Tabel 4.

Berdasarkan angket tanggapan mahasiswa, kelebihan buklet ini adalah materi dengan gambar, kejelasan materi serta tampilan yang menarik. Pengalaman mahasiswa menggunakan buklet dalam pembelajaran bukan yang pertama kali karena mahasiswa pernah menggunakan buklet dalam pembelajaran lain, tetapi untuk pembelajaran Sejarah barulah yang pertama. Mahasiswa memberikan tanggapan yang sangat baik terhadap pembelajaran materi sejarah lokal perekonomian menggunakan buklet. Hal ini ditunjukkan dengan rata-rata skor keselurahan sebanyak 92,5\% dengan kategori sangat layak.

Tabel 4. Rekapitulasi tanggapan mahasiswa

\begin{tabular}{|c|l|c|c|c|}
\hline No & \multicolumn{1}{|c|}{ Pernyataan } & $\begin{array}{c}\text { Reg A } \\
\text { Ya \% }\end{array}$ & $\begin{array}{c}\text { Reg C } \\
\text { Ya \% }\end{array}$ & Rata-rata \\
\hline 1. & Pengalaman buklet pertama kali & 66 & 65 & 66,5 \\
\hline 2. & Kemudahan penggunaan & 100 & 100 & 100 \\
\hline
\end{tabular}




\begin{tabular}{|c|l|c|c|c|}
\hline 3. & Kemudahan bahasa & 100 & 100 & 100 \\
\hline 4. & Meningkatkan motivasi dan minat belajar & 97 & 85 & 91 \\
\hline 5. & Kemenarikan isi & 100 & 100 & 100 \\
\hline 6. & Pemahaman materi & 97 & 94 & 95,5 \\
\hline 7. & Belajar secara mandiri & 83 & 91 & 87 \\
\hline 8. & Belajar secara kelompok & 97 & 100 & 98,5 \\
\hline 9. & Kepraktisan & 100 & 97 & 98,5 \\
\hline 10. & Gambar meningkatkan pemahaman & 94 & 100 & 100 \\
\hline 11. & $\begin{array}{l}\text { Meningkatkan kemampuan berfikir } \\
\text { kesejarahan }\end{array}$ & 94 & 91 & 85 \\
\hline Rata-rata & & & 76 & 92,5 \\
\hline
\end{tabular}

Menurut mahasiswa, penggunaan buklet dalam pembelajaran tidak dapat lepas dari peran seorang Dosen, mahasiswa tetap membutuhkan arahan untuk memperoleh informasi yang disampaikan. Hal ini didukung Setiawan (2008) yang menyatakan bahwa proses pembelajaran sejarah yang dilakukan guru hendaknya memungkinkan terjadinya pengembangan pemahaman konsep, sikap, dan meningkatkan minat mahasiswa terhadap pelajaran sejarah. Mahasiswa dapat menggali pengetahuan dan pengalaman sendiri. Peran dosen dalam pembelajaran hanya sebagai pemandu dan fasilitator.

Beberapa hal yang dianggap mahasiswa sebagai kelebihan buklet antara lain $100 \%$ mahasiswa menilai buklet memiliki kemudahan dalam penggunaan karena desain yang sederhana, ringkas, namun tetap variatif dibandingkan dengan buku pelajaran, 100\% mahasiswa mengganggap bahasa yang digunakan lebih mudah dipahami dan lebih komunikatif sehingga 95,5\% mahasiswa dapat memahami materi yang ada dalam buklet dengan didukung penggunaan gambar, 91\% mahasiswa menganggap buklet dapat meningkatkan motivasi dan gairah belajar karena sebagian mahasiswa senang dengan hal yang baru dan dengan adanya buklet ini sebagai sumber belajar mahasiswa dapat belajar kapanpun, namun sebagian mahasiswa lebih senang dengan observasi langsung, 100\% menilai buklet memiliki isi yang menarik karena dilengkapi dengan hasil penelitian, gambar berwarna serta penjelasan yang mudah dimengerti. Penilaian terhadap kepraktisan buklet sangat baik (98\% mahasiswa), buklet mudah dibawa, ringan, dan materi yang sudah terangkum sehingga ringkas dan mudah 
dipahami karena berkaitan dengan sejarah, $85 \%$ mahasiswa juga berpendapat bahwa materi dalam buklet mampu menumbuhkan dan meningkatkan kompetensi sejarah lokal perekonomian. Menurut Kasrina et al. (2012), pemanfaatan sumber belajar akan dapat membantu dan memberikan kesempatan siswa, berpartisipasi memberikan pengalaman belajar yang konkret, sehingga tujuan pembelajaran dapat dicapai dan dapat membangkitkan motivasi dan minat belajar siswa.

Selain ranah kognitif, ranah afektif berupa angket peduli terhadap sejarah lokal juga diberikan kepada mahasiswa. Melalui angket ini dosen mengetahui tingkat kepedulian mahasiswa terhadap sejarah lokal. Rekapitulasi skor afektif mahasiswa mengenai kepedulian terhadap sejarah lokal tercantum dalam Tabel 5.

Tabel 5. Skor afektif siswa

\begin{tabular}{|c|c|c|c|c|}
\hline \multicolumn{2}{|c|}{ Psychological scale score } & \multirow{2}{*}{ Category } & \multicolumn{2}{c|}{$\begin{array}{c}\text { Number Of Students } \\
2015\end{array}$} \\
\cline { 3 - 5 } & & Reguler & $\begin{array}{c}\text { C Reguler } \\
2015\end{array}$ \\
\hline 1. & $75 \% \leq \mathrm{P}<100 \%$ & Very high & 33 & 31 \\
\hline 2. & $50 \% \leq \mathrm{P}<75 \%$ & High & 2 & 3 \\
\hline 3. & $25 \% \leq \mathrm{P}<50 \%$ & Low & - & - \\
\hline 4. & $0 \% \leq \mathrm{P}<25 \%$ & Very low & - & - \\
\hline Average & $88 \%$ & Very high & & \\
\hline
\end{tabular}

Berdasarkan Tabel 5, diperoleh rata-rata persentase skor afektif mahasiswa mencapai 88\% dengan perincian sebagai berikut, 95\% mahasiswa A Reguler 2015 memiliki karakter berfikir kesejarahan sangat tinggi artinya 33 siswa memiliki skor sangat tinggi dan 2 siswa memiliki skor tinggi sedangkan 91\% siswa kelas C Reguler 2015 memiliki karakter peduli sejarah lokal sangat tinggi dengan 31 mahasiswa dengan skor sangat tinggi dan 3 mahasiswa dengan skor tinggi.

Secara keseluruhan penilaian afektif mengenai karakter berfikir kesejarahan dan hasil belajar mahasiswa cukup tinggi. Wardani (2012) yang menyatakan bahwa penanaman nilai karakter mempunyai pengaruh besar terhadap hasil belajar karena karakter mencakup integritas, moral yang baik yang diolah bersama kecerdasan.

Pembentukan karakter cinta sejarah dimulai dari pengetahuan dasar siswa mengenai sejarah. Mahasiswa mengetahui konsep dasar dalam materi sejarah. Mahasiswa dilatih pengetahuan dasarnya melalui diskusi kelompok I dalam buklet. 
Pengetahuan dasar mahasiswa digunakan untuk melakukan pencarian informasi mengenai masalah-masalah sejarah yang terjadi di lingkungan lokal terkait materi sejarah lokal perekonomian. Mahasiswa mengetahui masalah-masalah lokal yang terjadi di lingkungannya melalui informasi tersebut. Setelah siswa mengetahui masalah yang ada, timbul kepedulian pada siswa. Kepedulian tersebut mengantarkan siswa untuk menganalisis dan mencari solusi yang dapat digunakan untuk mengatasi masalah tersebut. Tugas tersebut terdapat dalam dikusi kelompok II. Science process skills siswa berkembang sejalan dengan kegiatan inkuiri (Martin 2005). Siswa dituntun untuk dapat mengamati lingkungan serta mencari tahu informasi berkaitan dengan tugas yang ada pada diksusi kelompok. Aktivitas tersebut menjadikan siswa tidak hanya paham materi sejarah perekonomian, tetapi juga dapat menanamkan rasa cinta terhadap sejarah.

Pembelajaran menggunakan buklet berbasis penelitian memberikan pengaruh positif terhadap hasil belajar dan nilai afektif mahasiswa. Penggunaan buklet mempunyai keunggulan, seperti yang dikemukakan oleh Citrawathi (2009) antara lain (1) bersifat konkret, (2) mengatasi batasan ruang dan waktu, (3) mengatasi keterbatasan pengamatan, (4) memperjelas suatu masalah, dan (5) dikemas dengan relatif mudah digunakan. Buklet hasil penelitian dilengkapi dengan lembar diskusi mahasiswa yang berisi permasalahan berfungsi untuk menambah pemahaman mahasiswa. Permasalahan-permasalahan yang terdapat dalam buklet dapat dikerjakan mahasiswa secara berkelompok dengan metode diskusi. Metode diskusi adalah cara penyampaian materi dengan menganalisis, menggali, atau memperdebatkan permasalahan untuk memperoleh penyelesaian (Majid 2009). Metode ini bermanfaat untuk menghubungkan materi dengan kehidupan nyata serta memberi kesempatan kepada siswa untuk berpartisipasi sehingga dapat membantu berlangsungnya proses belajar mengajar yang berpusat pada mahasiswa. Penerapan metode diskusi membantu mahasiswa dalam memahami materi karena mahasiswa dapat bertukar pikiran serta menciptakan suasana kelas yang produktif dan menyenangkan. Metode diskusi kelompok menggunakan buklet dapat diterapkan dalam pembelajaran. Berdasarkan 
penilaian mahasiswa tersebut menunjukkan bahwa buklet efektif digunakan sebagai sumber belajar materi sejarah lokal perekonomian.

\section{PENUTUP}

Buklet dikembangkan berdasarkan hasil analisis angket kebutuhan pengembangan oleh guru dan angket observasi awal oleh mahasiswa. Pengembangan buklet berbasis penelitian merupakan proses pembuatan bahan ajar materi Sejarah lokal perekonomian dengan penambahan jurnal ilmiah yang dirancang secara menarik menggunakan aplikasi desain grafis.

Buklet berbasis penelitian efektif digunakan sebagai sumber belajar terlihat dari hasil belajar mahasiswa pada materi sejarah lokal perekonomian mencapai ketuntasan belajar $\geq 80 \%$ dengan nilai $\geq 80$ serta layak digunakan dengan rata-rata hasil penilaian validator materi dan media sebesar $91,5 \%$.

\section{Daftar Pustaka}

Agung, Leo, 2013. Perencanaan Pembelajaran Sejarah. Yogyakarta : Ombak. Depdiknas. 2008. Kurikulum Tingkat Satuan Pendidikan. Jakarta : Dikmenum. Hamalik, Oemar. 1995. Kurikulum dan Pembelajaran. Jakarta : Bumi Aksara. Kochar, 2008.Pembelajaran Sejarah Teaching of History. Jakarta. Grasindo. Moleong, Lexy. 2006. Metodologi Penelitian Kualitatif (Edisi Revisi). Bandung: Prastowo, Andi. 2014. Panduan Kreatif Membuat bahan Ajar Inovatif. Yogyakarta: DIVA Press.

Solihatin, Etin dan Raharjo. 2008. Cooperative Learning Analisis Model Pembelajaran IPS. Jakarta: Bumi Aksara.

Sudjana, Nana. 2004. Dasar-Dasar Proses Belajar Mengajar. Bandung : Sinar Baru Algesindo

Sugiyono. 2008. Metode Penelitian Kuantitatif, Kualitatif, dan R\&D. Bandung: Alfabeta.

Sukmadinata, Nana Syaodih. 2013. Metode Penelitian Pendidikan. Bandung : PT Remaja Rosdakarya

Wasino. 2007. Dari Riset Hingga Tulisan Sejarah. Semarang: UNNES Press. 2010. Buku Ajar Sebagai Bahan Ajar Yang Mencerdaskan dan Mindfull Wena, made. 2009. Strategi pembelajaran inovatif kontemporer suatu tinjauan konseptual operasional. Jakarta:Bumi Aksara.

Wiyanarti, Erlina. (2012). Model Pembelajaran Kontekstual dalam pengembangan pembelajaran Sejarah. Bahan Ajar. Bandung : UPI 